\title{
Effect of Oxidative Stress on DNA Repairing Genes
}

\author{
Bedia Cakmakoglu, Zeynep Birsu Cincin and Makbule Aydin \\ Istanbul University, Institute for Experimental Medicine Research, \\ Turkey
}

\section{Introduction}

Oxidative DNA damage has been thought to contribute to the general decline in cellular functions that are associated with a variety of diseases including Alzheimer disease, amyotrophic lateral sclerosis (ALS), Parkinson's disease, atherosclerosis, ischemia/reperfusion neuronal injuries, degenerative disease of the human temporomandibular-joint, cataract formation, macular degeneration, degenerative retinal damage, rheumatoid arthritis , multiple sclerosis , muscular dystrophy, diabetes mellitus, human cancers as well as the aging process itself. Oxidative stress occurs when the production of the reactive oxygen species (ROS) exceeds natural antioxidant defence mechanisms. There are several sources that form the ROS. Most of ROS come from the endogenous sources as by-products of normal and essential metabolic reactions, such as energy generation from mitochondria or the detoxification reactions involving the liver cytochrome $P-450$ enzyme system. There are also exogenous ROS sources including exposure to cigarette smoke, environmental pollutants such as emission from automobiles and industries, consumption of alcohol in excess, asbestos, exposure to ionizing radiation, and bacterial, fungal or viral infections. ROS cause damage to biomolecules such as lipid, proteins and DNA by attaching. ROS may directly attack DNA, either the sugar, phosphate or purine and pyrimidine bases. On the other hand, oxidative damage may be indirect by rising of intracellular $\mathrm{Ca}^{+2}$ ions. Free radical-mediated reactions can cause structural alterations in DNA (e.g., nicking, base-pair mutations, rearrangement, deletions insertions and sequence amplification). Degradation of the bases will produce numerous products, including 8-OH-Gua, hydroxymethylurea, urea, thymine glycol; thymine and adenine ring opened and saturated products. Most oxidized bases in DNA are repaired by base excision repair (BER). BER consists of four main steps. The first step involves the removal of the oxidised base by a specific DNA glycosylase, yielding an apurinic/apyrimidinic (AP) site. In the second step, an AP endonuclease removes the deoxyribose phosphate group from the AP site generating a single nucleotide gap. A DNA polymerase, thought to be predominantly DNA polymerase $b$, fills this gap. Finally, a DNA ligase, probably DNA ligase III, seals the stand break and completes the repair process.

This chapter mainly deals with: (i) formation of ROS in physiological and pathological conditions, (ii ) ROS-mediated DNA damage, leading to cellular pathology and ultimately to cell death (iii) Oxidative DNA damage repair systems, (iv) The molecular mechanism of ROS-mediated diseases such as cancer, cardiovascular disease, neurodegenerative diseases, inflammatory disease, ischemia-reperfusion injury and aging. 
If the mechanisms of oxidative DNA damage and DNA repairing system are well understood, the diseases resulting from oxidative DNA damage or inefficient DNA repairing could be treated in future and a better understanding of these mechanisms would also allow biomarkers of DNA damage to become potentially useful clinical tools.

\section{Formation of reactive oxygen species}

Oxygen $\left(\mathrm{O}_{2}\right)$ is an element obligatory for life and living systems have evolved to survive in the presence of molecular $\mathrm{O}_{2}$. Oxidative properties of $\mathrm{O}_{2}$ play a vital role in diverse biological phenomena. $\mathrm{O}_{2}$ has double-edged properties, being essential for life; it can also aggravate the damage within the cell by oxidative events. This situation is referred to as the "Oxygen Paradox" [Sen et al., 2010; Khanna \& Shiloh, 2009].

Aerobic organisms are constantly subjected to a variety of reactive entities derived from molecular $\mathrm{O}_{2}$, often collectively referred to as reactive oxygen species (ROS). Some ROS contain unpaired electrons and are therefore referred to as free radicals. A radical is an atom or group of atoms that have one or more unpaired electrons. Radicals can have positive, negative or neutral charge. A prominent feature of radicals is that they have extremely high chemical reactivity, which explains not only their normal biological activities, but also how they inflict damage on cells. There are many types of radicals, but in biological systems most significant are those derived from $\mathrm{O}_{2}$ [Khanna \& Shiloh, 2009, Colton \& Gilbert, 1999]. The radicals derived from the reduction of molecular oxygen: superoxide/hydroperoxyl radicals hydrogen peroxide and the hydroxyl radical $\left({ }^{\circ} \mathrm{OH}\right)$ the species derived from the reaction of carbon-centered radicals with molecular oxygen: peroxyl radicals alkoxyl radicals and organic hydroperoxides ( $\mathrm{ROOH})$; and other oxidants resulting in free radical formation such as hypochlorous acid (HOC1), peroxynitrite and singlet $\mathrm{O}_{2}$ [Khanna \& Shiloh, 2009, Colton \& Gilbert, 1999].

The diatomic oxygen molecule qualifies as a radical, because it possesses two unpaired electrons, each located at a different orbital. Since both electrons have the same quantum spin number, $\mathrm{O}_{2}$ itself has relatively low reactivity. Another radical derived from $\mathrm{O}_{2}$ is singlet oxygen, ${ }^{1} \mathrm{O}_{2}$. This is an excited form of $\mathrm{O}_{2}$ in which one of the electrons jumps to a superior orbital following absorption of energy. For $\mathrm{O}_{2}$ to oxidize a molecule directly, it would have to accept a pair of electrons with a spin opposite to that of the $\mathrm{O}_{2}$. In biological systems, $\mathrm{O}_{2}$ can accept an electron and form one of the following species: superoxide anion $\left(\cdot \mathrm{O}_{2}^{-}\right), \cdot \mathrm{OH}$, or hydrogen peroxide $\left(\mathrm{H}_{2} \mathrm{O}_{2}\right)$. These molecules possess various degrees of reactivity with nonradical compounds [Colton \& Gilbert, 1999, Kohen \& Nyska, 2002].

The mitochondrial respiratory chain is the major source of $\bullet^{\mathrm{O}_{2}-}$, [Colton \& Gilbert, 1999, Kohen \& Nyska, 2002, Bielski \& Cabelli, 1995, Halliwell \& Gutteridge, 1999, Schafer \& Buettner, 2001, Forman \& Boveris, 1982]. $\cdot \mathrm{O}_{2}-$ is abundant and can reach an intracellular concentration of about 10-11 M [Halliwell \& Gutteridge, 1999, Schafer \& Buettner, 2001, Forman \& Boveris, 1982, Babior, 2000, Nohl \& Hegner, 1978]. $\bullet^{\cdot} \mathrm{O}_{2}-$ is not highly reactive for biological molecules however once formed it quickly undergoes dismutation to generate hydrogen peroxide, which is highly reactive. This reaction is markedly accelerated by a family of enzymes, the superoxide dismutases (SODs). ${ }^{\cdot} \mathrm{O}_{2}{ }^{-}$can react with $\mathrm{H}+$ to form $\mathrm{HO}_{2}{ }^{\bullet}$ (hydroperoxy radical) which is much more reactive than ${ }^{\cdot} \mathrm{O}_{2}{ }^{-}$. NADPH oxidase, primarily located in phagocytes, neutrophils and monocytes, can generate $\cdot \mathrm{O}_{2}{ }^{-}$and other reactive oxidants that are used for fighting invading microorganisms [Sohal, 1997]. 
The $\cdot \mathbf{O H}$ is an extremely reactive oxidant [Halliwell \& Gutteridge, 1999, Khanna \& Shiloh, 2009]. It is also a short-lived molecule with an estimated half-life of nanoseconds at $37^{\circ} \mathrm{C}$, traveling only a few Ångstroms. Despite its short life span, $\cdot \mathrm{OH}$ is capable of inducing considerable damage to nuclear and mitochondrial DNA. This radical alone can cause over 100 types DNA modifications [Khanna \& Shiloh, 2009, Michalik et al., 1995]. In addition, - $\mathrm{OH}$ can lead to lipid peroxidation and oxidation of amino acids, sugars, and metals. The $\cdot \mathrm{OH}$ is a major product of irradiation due to radiation-induced dissociation of water molecules.

Although $\mathrm{H}_{2} \mathrm{O}_{2}$ itself is not a radical, it is included in ROS due to producing highly reactive free radical, $\cdot \mathrm{OH} . \mathrm{H}_{2} \mathrm{O}_{2}$ is one of the most stable ROS and acts as a messenger in cellular signaling pathways [Khanna \& Shiloh, 2009, Kamata \& Hirata, 1999]. There are some enzymes that can produce $\mathrm{H}_{2} \mathrm{O}_{2}$ directly or indirectly, including SOD, monoamine oxidase (MAO), diamine and polyamine oxidase, and glycolate oxidase. Under normal conditions, $\mathrm{H}_{2} \mathrm{O}_{2}$ is not toxic up to a cellular concentration of about $10^{-8} \mathrm{M}$ [Imlay et al., 1988] $\mathrm{H}_{2} \mathrm{O}_{2}$ molecules are freely dissolved in aqueous solution and can easily penetrate biological membranes. Their deleterious chemical effects can be divided into the categories of direct activity, originating from their oxidizing properties, and indirect activity in which they serve as a source for more deleterious species, such as $\mathrm{OH}$. or $\mathrm{HClO}$. In the presence of transition metals such as $\mathrm{Fe}^{2+}$ or $\mathrm{Cu}^{+}, \mathrm{H}_{2} \mathrm{O}_{2}$ it can be converted to highly reactive ${ }^{\bullet} \mathrm{OH}$, either by Fenton or Harber- Weiss reactions [Yamasaki \& Piette, 1991, Halliwell \& Gutteridge, 1999, Khanna \& Shiloh, 2009]. $\mathrm{H}_{2} \mathrm{O}_{2}$ is detoxified by a set of enzymes that includes the selenium-dependent glutathione peroxidase (GPx) and catalase.

The nitric oxide (NO), or nitrogen monoxide, which is a radical $\left(\mathrm{NO}^{\bullet}\right)$, is produced by the oxidation of one of the terminal guanido nitrogen atoms of L-arginine. In this reaction, Larginine is converted to NO and L-citrulline by nitric oxide synthase (NOS) which has three isoforms: neuronal NOS, endothelial NOS (eNOS), and inducible NOS (iNOS). NO is quite stable and benign for a free radical, with a lifetime of several seconds. Under normal conditions, NO has many physiological functions such as a neuronal messenger and modulator of smooth muscle contraction. $\mathrm{NO}$ can interact with $\cdot \mathrm{O}_{2}-$ to form the peroxynitrite anion (ONOO-) that induces a cascade of events that can eventually lead to cell death [Radi et al., 1991a]. This molecule accounts for much of the NO toxicity. The reactivity of $\mathrm{ONOO}-$ is roughly the same as that of $\bullet \mathrm{OH}$ and $\mathrm{N}_{2}{ }^{\bullet}$. Its toxicity is derived from its ability to directly nitrate and hydroxylate the aromatic rings of amino acid residues [Schafer \& Buettner, 2001] and to react with sulfahydryls [Beckman et al., 1992], lipids [Radi, 1991b], proteins [Moreno \& Pryor, 1992] and DNA [King et al., 1992]. Under physiological conditions, $\mathrm{ONOOH}$ can react with other components present in high concentrations, such as $\mathrm{H}_{2} \mathrm{O}_{2}$ or $\mathrm{CO}_{2}$, to form an adduct that might be responsible for many of the deleterious effects seen in biological sites. Peroxynitrite anion can also affect cellular energy status by inactivating key mitochondrial enzymes [Radi et. Al, 1994], and it may trigger calcium release from the mitochondria [Packer \& Murphy, 1994].

\section{Classification of reactive oxygen species}

ROS generated in response to both endogenous and exogenous stimuli can be divided into Endogenous ROS and exogenous ROS. (Figure 1) [Ziech et al., 2010, Fukai \& Nakamura, 2008, Klaunig \& Kamendulis, 2004, Galaris et al., 2008]. 


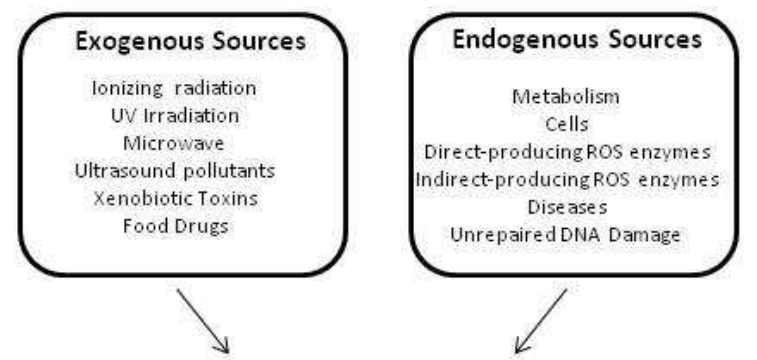

FORMATION OF RADICAL OXYGEN SPECIES

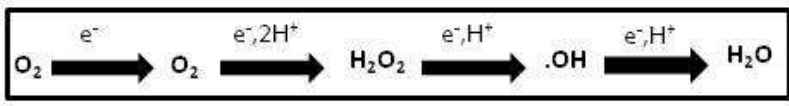

TYPES OF DNA DAMAGE BY FREE RADICALS

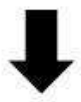

SITES OF OXIDATIVE DAMAGE IN DNA

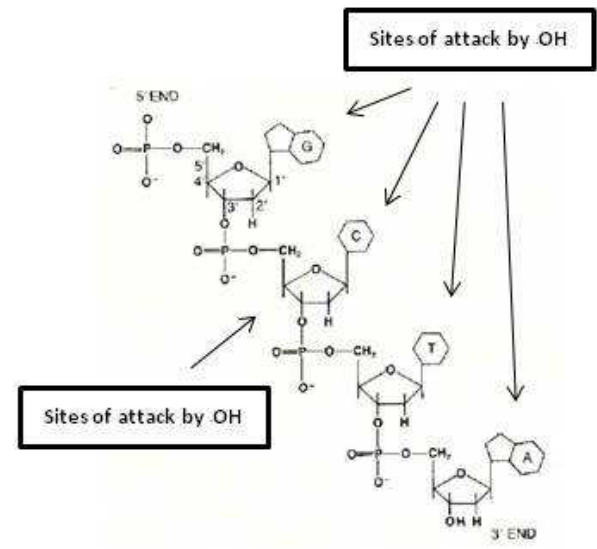

BASE EXCISION REPAIR (BER)
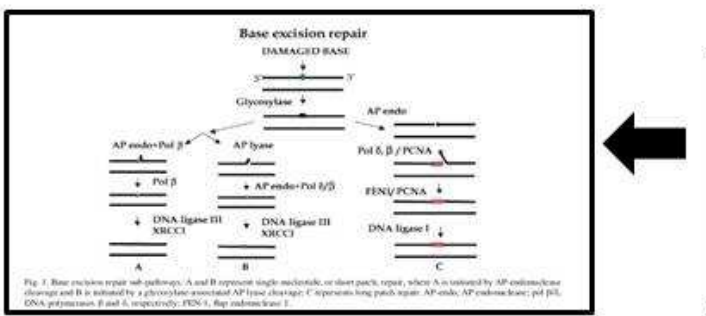

DNA sugar damage

DNA-protein cross links

sinle and double-strand breaks Abasic sites

DNA base damage

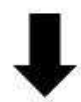

REACTIONS OF HYDROXY RADICAL WITH PURINES

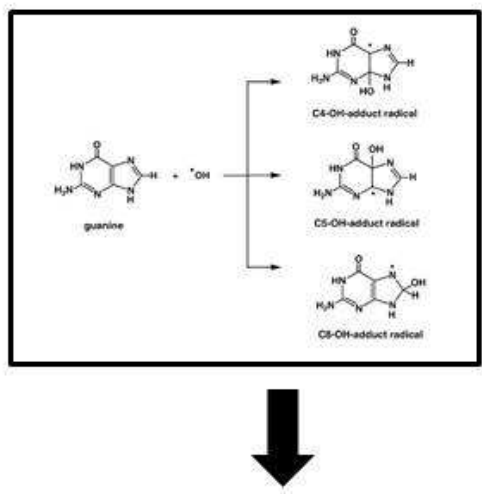

FORMATION OF PURINE PRODUCTS

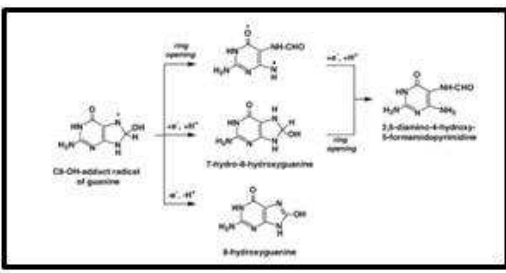

Fig. 1. Oxidative damage and repair of DNA. 


\section{Endogenous ROS}

In eukaryotic cells, aerobic respiration in the mitochondria is the main source for the generation of ROS. ROS are also produced by peroxisomal oxidation of fatty acids, microsomal cytochrome P450 metabolism of xenobiotic compounds, stimulation of phagocytosis by pathogens or lipopolysaccharides, arginine metabolism and tissue specific enzymes [Adly, 2010]. Enzymes in the cytosol, such as oxygenases, peroxidases and oxidases, generate small amounts of ROS. It is estimated that more than $95 \%$ of ${ }^{\cdot} \mathrm{O}_{2}{ }^{-}$ produced during normal metabolism are generated as a by-product from the electron transfer reactions at the inner mitochondrial membrane. Approximately 1-2\% of the $\mathrm{O}_{2}$ consumed by mitochondria is converted into ${ }^{\circ} \mathrm{O}_{2}{ }^{-}$[Cadenas \& Davies, 2000, Hashiguchi et al., 2004].Because of such a highly oxidative environment, mitochondria are also one of the main cellular targets of ROS induced damage, and in fact relatively high levels of oxidized proteins, lipids and nucleic acids are detected in mammalian mitochondria under normal metabolic conditions [Hashiguchi et al., 2004, Raha \& Robinson, 2000].

Another significant endogenous source of ROS production is via the reduction of molecular $\mathrm{O}_{2}$ by inflammatory cells [Klaunig \& Kamendulis, 2004, Ziech et al., 2010, Fukai \& Nakamura, 2008]. In this reaction, phagocytes produce ${ }^{\cdot} \mathrm{O}_{2}{ }^{-}$via oxygen's monovalent reduction. In order to counterbalance ROS-mediated injury, endogenous antioxidant defense systems exist and function by quenching and clearing intracellular ROS activity and accumulation and maintaining redox equilibrium [Ziech et al., 2010, Dizdaroğlu et al., 1993]. Generated chronic oxidative stress damage to cellular macromolecules like DNA, lipids and proteins [Klaunig \& Kamendulis, 2004, Ziech et al., 2010]. The endogenous enzymatic antioxidant defenses (SOD, GPx and catalase) can counterbalance oxidative microenvironments by chelating superoxide and various other peroxides. Also, the non-enzymatic endogenous antioxidants (Vitamins $\mathrm{E}$ and $\mathrm{C}$, coenzyme $\mathrm{Q}, \mathrm{B}$-carotene and glutathione) have the ability to eliminate ROS activity. Thus, ROS can be considered as critical determinants of intracellular redox states and thus serve as important cellular regulatory mechanism(s) in both health and disease [Klaunig \& Kamendulis, 2004, Ziech et al., 2010].

\section{Exogenous ROS}

Environmental agents like radiation, xenobiotics and chlorinated compounds are significant inducers of cellular damage via ROS mediated toxicity [Galaris et al., 2008]. In addition, anticancer drugs, anesthetics, analgesics, trauma; radiation; electromagnetic fields; alcohol; cigarette smoke; medications; stress; allergens; cold, excessive exercise; dietary factors such as excess sugar, saturated fat and fried oils; malnutrition and various disease states have been considered as most established environmental sources of ROS [Cadenas \& Davies, 2000]. Furthermore, exposure to ionizing and ultraviolet radiations also induces ROS-mediated alterations in major pathways associated with the control of cellular growth and survival. For instance, ultraviolet B rays can damage DNA directly and also increase ROS concentrations in epidermal cells [Mena et al., 2009]. In addition, urban air contains a mixture of oxidizing gases and particulates arising from a variety of sources, such as power plants, motor vehicles, wildfires and waste incinerators. Chronic exposure to polluted air induces irreversible damage to cellular macromolecules (DNA, proteins, lipids etc.) via ROS production and their accumulation in cells and tissues [Moller et al., 2008]. Metabolism of exogenous sources of ethanol and phenobarbital contributes to ROS generation through changes in the cytochrome P450 pathway [Wu \& Cederbaum, 2003]. 


\section{ROS-mediated DNA damage}

Although DNA is a stable and well-protected molecule, ROS can interact with it and cause several types of damage: modification of DNA bases, single- and double-DNA breaks, loss of purines (apurinic sites), damage to the deoxyribose sugar, DNA-protein cross-linkage, and damage to the DNA repair system (Figure 1) [Kohen \& Nyska, 2002].

Of the ROS, the highly reactive $\bullet \mathrm{OH}$ reacts with DNA by addition to double bonds of DNA bases and by abstraction of an $\mathrm{H}$ atom from the methyl group of thymine and each of the $\mathrm{C}$ $\mathrm{H}$ bonds of 2'-deoxyribose. Addition of $\bullet \mathrm{OH}$ to the $\mathrm{C} 5-\mathrm{C} 6$ double bond of pyrimidines leads to $\mathrm{C} 5-\mathrm{OH}$ and $\mathrm{C} 6-\mathrm{OH}$ adduct radicals of cytosine and thymine and $\mathrm{H}$ atom abstraction from thymine results in the allyl radical. Adduct radicals differ in terms of their redox properties, $\mathrm{C} 5-\mathrm{OH}-$ and $\mathrm{C} 6-\mathrm{OH}$-adduct radicals of pyrimidines possess reducing and oxidising properties, respectively [Sonntag, 1987, Steenken, 1987, Teoule, 1987, Cooke et al., 2003].

Pyrimidine $\mathrm{OH}$-adduct radicals and the allyl radical are oxidised or reduced depending on their redox environment, redox properties and reaction partners, yielding a variety of products [Dizdaroglu, 1992, Evans et al., 2004]. Product types and yields depend on absence and presence of $\mathrm{O}_{2}$ and on other conditions [Cooke et al., 2003, Breen \& Murphy, 1995]. In the absence of $\mathrm{O}_{2}$, the oxidation of $\mathrm{C} 5-\mathrm{OH}$ adduct radicals, followed by addition of $\mathrm{OH}_{-}$(or addition of water followed by deprotonation), leads to cytosine glycol and thymine glycol. The oxidation of the allyl radical of thymine yields 5-hydroxymethyluracil (5-OHMeUra) when molecular $\mathrm{O}_{2}$ adds to $\mathrm{C} 5-\mathrm{OH}$-adduct radicals at diffusion-controlled rates generating C5-OH-6-peroxyl radicals, which subsequently eliminate $\mathrm{O}_{2} \bullet-$ followed by reaction with water (addition of $\mathrm{OH}^{-}$) to yield thymine and cytosine glycols [Evans et al., 2004, Sonntag, 1987, Teoule, 1987].

Addition of $\mathrm{O}_{2}$ to the allyl radical leads to 5-OHMeUra and 5-formyluracil (5-FoUra). Pyrimidine peroxyl radicals are also reduced and then protonated to give hydroxyhydroperoxides [Teoule, 1987], which decompose and yield thymine glycol, 5OHMeUra, 5-FoUra, and 5-hydroxy-5-methylhydantoin [Wagner et al., 1994, Dizdaroglu et al., 1993a].

Cytosine products may deaminate and dehydrate. Cytosine glycol deaminates to give uracil glycol, 5-hydroxycytosine (5-OH-Cyt), and 5-hydroxyuracil (5-OH-Ura) that are unique in that they can deaminate and dehydrate. However, there is evidence that these four compounds (cytosine glycol, uracil glycol, 5-OH-Cyt, and 5-OH-Ura) may simultaneously be existed damaged DNA [Wagner et al., 1994, Dizdaroglu et al., 1993a]. In the absence of $\mathrm{O}_{2}$, $\mathrm{C} 5-\mathrm{OH}$ adduct radicals may be reduced, followed by protonation to give rise to 5-hydroxy-6hydropyrimidines. 5-Hydroxy-6-hydrocytosine (5-OH-6-HCyt) readily deaminates into 5hydroxy-6-hydrouracil (5-OH-6-HUra). Similarly, C6-OH adduct radicals of pyrimidines are reduced yielding 6-hydroxy-5-hydropyrimidines. Formation of these products are inhibited in the presence of $\mathrm{O}_{2}$, because $\mathrm{O}_{2}$ reacts with their precursors $\mathrm{C} 5-\mathrm{OH}$ - and C6-OH-adduct radicals at diffusion-controlled rates to yield peroxyl radicals and then other products.

Further reactions of $\mathrm{C} 5-\mathrm{OH}-6-$ peroxyl and $\mathrm{C} 6-\mathrm{OH}-5$-peroxyl radicals of cytosine result in formation of 4-amino-5-hydroxy-2, 6(1H, 5H)-pyrimidinedione and 4-amino-6-hydroxy-2, $5(1 \mathrm{H}, 6 \mathrm{H})$-pyrimidinedione, respectively. The former deaminates to give dialuric acid, which is readily oxidised to yield alloxan [Dizdaroglu et al., 1993a, Behrend et al., 1989, Dizdaroglu 1993b]. The presence of alloxan in damaged DNA has been shown by its release from DNA by E. coli Nth [Dizdaroglu et al., 1993a]. 
Decarboxylation of alloxan yields 5-hydroxyhydantoin (5-OH-Hyd) upon acidic treatment. Isodialuric acid is formed by deamination of 4-amino-6-hydroxy-2, $5(1 \mathrm{H}, 6 \mathrm{H})$ pyrimidinedione. However, these two compounds may simultaneously exist in DNA as evidenced from the detection of their enol forms (5, 6-dihydroxycytosine (5, 6-diOH-Cyt) and 5, 6-dihydroxyuracil (5, 6-diOH-Ura), respectively) [11, 13]. 5-OH-6-hydroperoxide of cytosine undergoes intramolecular cyclisation to yield trans-1-carbamoyl-2-oxo-4, 5dihydroxyimidazolidine as a major product in cytosine [Kohen \& Nyska, 2002] However, this compound is formed as a minor product in DNA [Dizdaroglu et al., 1993a, Behrend et al., 1989, Dizdaroglu 1993b].

Hydroxyl adduct radicals of guanine are formed by addition of $\bullet \mathrm{OH}$ to the $\mathrm{C} 4-, \mathrm{C} 5-$ and $\mathrm{C} 8$ positions of guanine, generating $\mathrm{C} 4-\mathrm{OH}-, \mathrm{C} 5-\mathrm{OH}-$ and $\mathrm{C} 8-\mathrm{OH}-$ adduct radicals [O'Neill, 1983, Steenken, 1989, Candeisas \& Steenken, 2000]. The 6-substituted purines such as adenine undergo analogous reactions, yielding at least two $\mathrm{OH}$ adducts, are formed: $\mathrm{C} 4-\mathrm{OH}$ and C8-OH adduct radicals [Steenken, 1989, Candeisas \& Steenken, 2000]. C4-OH and C5$\mathrm{OH}$ adduct radicals of purines differ in their redox properties, with $\mathrm{C} 4-\mathrm{OH}$-adduct radicals being oxidising, and $\mathrm{C} 5-\mathrm{OH}$ - and $\mathrm{C} 8-\mathrm{OH}$-adduct radicals being primarily reducing.

On the other hand, different mesomeric structures of these radicals may be oxidizing or reducing, a phenomenon called "redox ambivalence" [Vieira \& Steenken, 1990]. Dehydration of $\mathrm{C} 4-\mathrm{OH}-$ and $\mathrm{C} 5-\mathrm{OH}-a d d u c t$ radicals of purines reconstitutes the purine by first yielding a purine $(-\mathrm{H})$ - radical, followed by reduction and protonation [Melvin et al., 1996]. The $\mathrm{C} 4-\mathrm{OH}$-adduct radical of guanine also eliminates $\mathrm{OH}$ - to give rise to the guanine radical cation (guanine $\bullet+$ ), which may deprotonate depending on $\mathrm{pH}$ to give guanine $(-\mathrm{H}) \bullet$ [Moreno \& Pryor, 1992]. Furthermore, on the basis of product analysis, the radical cation does not hydrate to lead to the $\mathrm{C} 8-\mathrm{OH}$ adduct radical and then to 8-hydroxyguanine by oxidation. However, it may react with $2^{\prime}$-deoxyribose in DNA by $\mathrm{H}$ abstraction, leading to DNA strand breaks [O'Neill \& Chapman, 1985].

This diversity has been explained by the notion that the hydration of guanine $\bullet+$ in ds-DNA may be much faster than that of monomeric guanine $\bullet+$ [Candeias \& Steenken, 2000]. $\mathrm{O}_{2}$ readily reacts with guanine $(-\mathrm{H}) \bullet$; however, its reaction with the $\mathrm{C} 4-\mathrm{OH}$-adduct radical of guanine is rather slow [Candeias \& Steenken, 2000]. The reaction of guanine(-H) $\bullet$ with $\mathrm{O}_{2}$ leads to imidazolone and oxazolone derivatives [Cadet et al., 1991]. However, this suggestion has not been confirmed by pulse radiolysis data and an alternative mechanism has been proposed [Melvin et al., 1996]. The C4-OH-adduct radical of adenine readily reacts with $\mathrm{O}_{2}$, however, final products of this reaction are not known [O'Neill \& Chapman, 1985]. C8-OH adduct radicals of purines may be oxidized by oxidants including $\mathrm{O}_{2}$. In contrast to $\mathrm{C} 4-\mathrm{OH}$ adduct radicals, their reaction with $\mathrm{O}_{2}$ is diffusion controlled [Vieira \& Steenken, 1990].

8-Hydroxypurines are formed in DNA by the one-electron oxidation of $\mathrm{C} 8-\mathrm{OH}$-adduct radicals [Bielski \& Cabelli, 1995, Halliwell \& Gutteridge, 1999] This reaction competes with the unimolecular opening of the imidazole ring by scission of the C8-N9 bond [Steenken, 1989, Candeias \& Steenken, 2000]. The one-electron reduction of the ring-opened radical leads to 2, 6-diamino-4-hydroxy-5-formamidopyrimidine (FapyGua) from guanine and 4, 6diamino-5-formamidopyrimidine (Fapy- Ade) from adenine [O'Neill, 1983, Breen \& Murphy, 1995]. The $\mathrm{C} 8-\mathrm{OH}$ adduct radicals may also be reduced without ring opening to give rise to 7-hydro-8-hydroxypurines, which, as hemiorthoamides, are converted into formamidopyrimidines. However, 8-Hydroxypurines and formamidopyrimidines are unique in that they are formed in DNA both in the absence and presence of $\mathrm{O}_{2}$, although $\mathrm{O}_{2}$ increases the yields of 8-hydroxypurines. Moreover, other experimental conditions highly 
affect the yields of these compounds, such as the presence of reducing or oxidizing agents [Dizdaroglu, 1992, Breen \& Murphy, 1995]. In the case of adenine, the $\bullet \mathrm{OH}$ attack at the C2position has also been proposed to take place and yield 2-hydroxyadenine (2-OH-Ade) when oxidation of the thus-formed C2-OH-adduct radical [Nackerdien et al., 1991]. Reactions of pyrimidines and purines result in multiple products in DNA. Most of these modified bases were identified in DNA in vitro and in vivo upon exposure to free radical generating systems [Dizdaroglu, 1998].

Reactions of $\bullet \mathrm{OH}$ with the sugar moiety of DNA by $\mathrm{H}$ abstraction give rise to sugar modifications. Some sugar products are released from DNA as free modified sugars, whereas others remain within DNA or constitute end groups of broken DNA strands. A unique reaction of the $\mathrm{C}^{5}$-centered sugar radical is the addition to the $\mathrm{C} 8$ - position of the purine ring of the same nucleoside. This intramolecular cyclisation followed by oxidation yields 8, 5'-cyclopurine-2' -deoxynucleosides [Dizdaroglu, 1986, Dirksen et al., 1988]. Both 5'R- and 5'S-diastereomers of 8, 5' -cyclo-2'-deoxyguanosine (cyclo-dG) and 8, 5'-cyclo-2'deoxyadenosine (cyclo-dA) are generated in DNA[Dizdaroglu, 1986, Dirksen et al., 1988]. $\left(5^{\prime} \mathrm{R}\right)$-and $\left(5^{\prime} \mathrm{S}\right)$ - cyclo-dGs were also identified in human cells exposed to ionizing radiation [Dizdaroglu, 1987]. These tandem lesions represent a concomitant damage to both the base and sugar moieties of DNA. $\mathrm{O}_{2}$ inhibits their formation by reacting with the $\mathrm{C}^{\prime}$ centered sugar radical before cyclization.

Another reaction of base radicals is the addition to an aromatic amino acid of proteins or combination with an amino acid radical, leading to DNA-protein cross-linking [Dizdaroglu, 1988]. Covalent DNA-protein cross-links are formed in cells in vivo or in chromatin in vitro by exposure to free radical-generating systems, e.g., ionising radiation. The formation of a thymine-tyrosine cross-link has been observed in mammalian chromatin in vitro and in living cells upon exposure to ionising radiation, $\mathrm{H}_{2} \mathrm{O}_{2}$, metal ions and carcinogenic compounds [Dizdaroglu et al. 1989, Nackerdien et al., 1991, Olinski et al., 1992, Altman et al., 1995]. The formation mechanism of DNA-protein cross-link has been proposed to involve the addition of the allyl radical of thymine in DNA to tyrosine in a protein, followed by oxidation. Chemical structures of other DNA base-amino acid cross-links have been identified in mammalian chromatin in vitro, but not in vivo [Dizdaroglu, 1998]

\section{Mechanism of oxidative DNA base damage: The BER pathway}

As mentioned above, excess ROS may induce oxidative DNA damage, DNA strand breaks, base modifications and chromosomal aberrations [Marnett, 2000]. For repair of the DNA damage, human cells have five DNA repair systems: Direct reversal, mismatch repair, double-strand break repair, base excision repair (BER) and nucleotide excision repair (NER) [Wood et al., 2001]. DNA lesions resulting from oxidative stress, as well as single strand breaks, are repaired via the BER pathway in organisms ranging from E. coli to mammals (Figure 1) [Hazra et al., 2007, Krokan et al., 2003].

It is believed that DNA-BER is the major pathway for repairing deaminated bases and bases with oxidative damage generated by ROS and can be used to repair alkylated bases [Hazra et al., 2007, Hedge et al., 2008]. BER has 4 main steps (i.e. base removal, AP site incision, synthesis, and ligation) and involves 4 major classes of DNA repair enzymes: DNA glycosylases, APE, DNA polymerases, and DNA ligases.

The proteins involved in this reaction function in concert to remove a damaged DNA base and replace it with the correct base. A currently accepted model for the BER pathway reveals five distinct enzymatic steps for the repair of damaged bases. 
Glycosylases at the initial step of BER. DNA glycosylases make BER possible - glycosylases recognize specific damaged bases and excise them from the genome, effectively initiating both longpatch and short-patch BER. To date, 11 different mammalian glycosylases have been characterized. The primary function of most DNA glycosylases is to recognize their substrate (the damaged base) and catalyze the cleavage of an $\mathrm{N}$-glycosidic bond, releasing a free base and creating an abasic site [Lindahl, 1974]. In addition to catalyzing the cleavage of $\mathrm{N}$-glycosydic bonds, some glycosylases are bifunctional having an additional AP lyase activity [O'Connor \& Laval, 1989]. The uracil-DNA glycosylase (UNG) was the first DNA glycosylase identified and cloned [Lindahl, 1974]. MPG, N-methylpurine-DNAglycosylase, and 8-oxoguanine-DNA glycosylase (OGG1)represent some extensively studied DNA glycosylases [Sedgwick et al., 2007, Kavli et al., 2007, Klungland \& Bjelland, 2007, Robertson et al., 2009]. After recognition of the damaged base by the appropriate DNA glycosylase, this glycosylase catalyzes the cleavage of an N-glycosidic bond, effectively removing the damaged base and creating an apurinic or apyrimidinic site (AP site). The DNA backbone is cleaved by either a DNA AP endonuclease or a DNA AP lyase - an activity present in some glycosylases. AP endonuclease activity creates a single-stranded DNA nick $5^{\prime}$ to the AP site, contrasting with the nick being created $3^{\prime}$ to the AP site as a result of activity ( $\beta$-elimination or $\beta$, $\delta$-elimination).

Repair can then proceed through one of two subpathways: short or long-patch BER. The short-patch BER involves the incorporation of a single nucleotide into the gap by DNA polymerase followed by strand ligation by DNA ligase. The long-patch BER involves incorporation of several nucleotides, typically two to seven, followed by cleavage of the resulting $5^{\prime}$ flap and ligation. Mitochondria possess independent BER machinery, the components of which are coded by nuclear genes.

Most DNA glycosylases have broad substrate specificities but can have preferences for either purines or pyrimidines. The major bifunctional glycosylase for purines is 8oxoguanine DNA glycosylase 1, which removes OHdG and 8-oxoG. Most oxidized pyrimidines are removed by endonuclease III-like protein, uracil DNA glycosylase (UNG), and Nei-like DNA glycosylase (NEIL-1 and NEIL-2). In human cells, there are at least 2 isoforms of OGG1 ( $\alpha$ and $\beta$ ) that arise from alternative splicing of products of the OGG1 gene [Boeiteux \& Radicella, 2000]. a-OGG1 is a 345-amino acid $(\sim 39 \mathrm{kd})$ protein that localizes to the nucleus and mitochondria, whereas $\beta$-OGG1 is a 424 -amino acid protein (47 $\mathrm{kd}$ ) that seems to localize exclusively to mitochondria [Boeiteux \& Radicella, 2000]. Because of the absence of an aO helix domain, $\beta$-OGG1 seems to lack glycosylase activity [Hashiguchi et al., 2004]. Endonuclease III-like protein 1 is a 312-amino acid ( 34 kd) protein that localizes to the nucleus. OGG1 and endonuclease III-like protein require duplex DNA for efficient repair. After the glycosylase reaction, the newly created nick is processed by the Apurinic/apyrimidinic endonuclease (APE), creating a single-nucleotide gap in the DNA. Importantly, the gap created contains a 3'- hydroxyl and a 5'-phosphate, substrates compatible with the downstream enzymatic reactions in BER.

APE cleaves intact AP sites by making a single nick 5' to the AP site to create $3^{\prime}-\mathrm{OH}$ and 5'deoxyribose phosphate termini that are removed by the activity of 3 '-OH and 5'-deoxyribose phosphatase proteins such as DNA Pol $\beta$. The 3-phosphate removal activity of APE is, however, approximately 70-fold lower than the AP endonuclease activity of APE [Winters et al., 1994], suggesting that other enzymes are important for the processing of damaged $3^{\prime}$ ends [Takahashi et al., 2007] APE is a 317-amino acid ( $\sim 37 \mathrm{kd})$ multifunctional protein localized to the nucleus [Demple et al., 1991]. In addition to its role in BER, APE is required 
for the redox activation of transcription factors (e.g. p53) spontaneously oxidized at cysteine residues in DNA binding domains to establish DNA binding activity [Jayaraman et al., 1997]. Deletion of APE in mice causes embryonic lethality [Jayaraman et al., 1997]. Cells from mice with APE haploinsufficiency respond poorly to oxidative stress [Meira et al., 2001].

The nick generated by the cleavage of the abasic site is filled in by either Pol $\beta$ or Pol $\delta / \varepsilon$ in the nucleus, and Pol $\gamma$ in the mitochondria. Pol $\gamma$ is the only DNA polymerase identified so far in vertebrate mitochondria and functions both as the replicative and the repair polymerase [Weissman et al., 2007, Kaguni, 2004]. Relevant to its role in BER, Pol $\gamma$ has a dRP-lyase activity and can catalyze the 3 '-end-processing necessary for short-patch BER [Longley et al., 1998].

The final step in the BER pathway is ligation of the nick with the correct nucleotide by DNA polymerases. An adenosine triphosphate-dependent DNA ligase (Ligase [Lig]I or III) completes the repair process and restores the integrity of the helix by sealing the nick. In the nucleus, two distinct DNA ligases participate in BER, ligase I, which has been implicated in long-patch BER, and ligase III, implicated in short-patch. The human ligase III gene (LIG3) also encodes for a mitochondrial variant, with a putative MTS generated by an alternative downstream translation initiation site [Lakshmipathy \& Campbell, 1999, Lakshmipathy \& Campbell, 2001]. The localization of ligase III protein to mitochondria suggests, then, that this enzyme may perform the ligation step in mtBER. Accordingly, reduction of ligase III expression using an antisense strategy resulted in an increase in breaks in mtDNA [Lakshmipathy \& Campbell, 2001].

\section{Diseases associated with defects of oxidative DNA damage repair systems}

It is quite new and non conclusive that oxidative DNA damage might result in diseases. Increasing numbers of oxidatively modified DNA lesions are proposed to be appropriate, intermediate biomarkers of a disease endpoint. For this reason alone, the association between oxidative DNA damage and disease should be determined. As seen above, it is clear that oxidative DNA damage has effects upon cells other than mutation. Nevertheless, DNA mutation is perhaps one of the most important consequences of lesion persistence, evidenced by the presence of multiple systems to prevent lesion formation and, should damage occur, ensure rapid lesion removal; with the DNA repair systems responsible for the latter having much overlap of substrates, as discussed previously [Evans et al., 2004].

Cumulative oxidative DNA damage have a significant effect of the impairment on normal cellular repair mechanisms. In fact, one of the main etiological hypotheses linking genomic instability, mutagenesis and tumorigenesis is that of deficient cellular repair mechanisms due to extensive oxidative DNA damage and cellular injury [Ziech, 2011]. Clearly, reduced repair will result in elevated lesions and an increased risk of disease [Cooke et al., 2003]. ROS-mediated DNA damage in addition to ineffective DNA repair mechanisms are well established lesions common to many life threatening human diseases, including neurodegenerative diseases, atherosclerosis, cancer, and aging has invoked free radical reactions as an underlying mechanism of injury [Ziech, 2011]. Given the importance of mutation in carcinogenesis, cancer will be the first disease in which a role for oxidative DNA damage in its aetiology is considered [Evans et al., 2004]. 


\section{Cancer}

The carcinogenicity of oxidative stress is primarily attributed to the genotoxicity of ROS in diverse cellular processes [ Ziech, 2011]. Oxidative mechanisms have been demonstrated to possess a potential role in the initiation, promotion, and malignant conversion (progression) stages of carcinogenesis [Cooke et al., 2003] . It has been suggested that some signaling system induces ROS that exhibit dual roles, cancer promoting and cancer suppresing, in tumorogenesis. ROS participate simultaneously in two signaling pathways that have inverse functions in tumorigenesis, Ras-Raf-MEK1/2-ERK1/2 signaling and the p38 mitogenactivated protein kinases (MAPK) pathway. Ras-Raf-MEK1/2-ERK1/2 signaling plays a role in oncogenesis, while the p38 MAPK pathway contributes to cancer suppression. The accumulation of intracellular ROS induced by oncogenic Ras is ERK-dependent during the activation of p38a [Pan et al., 2009)

Increased intracellular levels of ROS, induced by the Ras-Raf-MEK-ERK signaling cascade, may mediate the activation of the p38 pathway and act as an intermediate signal between the MEK-ERK and MKK3/6-p38 pathways. On the one hand, the activation of p38 mitogenactivated protein kinase (MAPK) is a prerequisite for ROS-mediated functions such as apoptotic cell death in cancer cells. On the other hand, inhibiting or scavenging ROS may attenuate the activation of p38-dependent pathways. Human cancer cell lines with high ROS levels display enhanced tumorigenicity and impaired p38a activation by ROS [Pan et al., 2009].

The effect of ROS by Ras may occur at the transcription level. GATA-6 is a component of the specific protein-DNA complexes at the nicotinamide adenine dinucleotide phosphate oxidase (Nox) 1 promoter, and is able to trans-activate the Nox1 promoter. GATA-6 is phosphorylated at serine residues by MEK-activated extracellular signal regulated kinase (ERK), which enhances GATA-6 DNA binding. The activity of the ROS-generating enzyme Nox1 is required for vascular endothelial growth factor (VEGF), a potent stimulator of tumor angiogenesis. Ras signaling enhances the transcription of Nox1 [Adachi et al., 2008]. A regulatory subunit, Rac, of the NADPH oxidase complex also involves the regulation of ROS [Heyworth et al., 1993, Kadara et al., 2008]. However, if extracellular signal-regulated kinase (ERK)-dependent phosphorylation of the transcription factor Sp1 and Sp1 binding to a VEGF promoter is inhibited, this activity does not occur [Pan et al., 2009].

Although some studies suggested that increased intracellular ROS elevate the activation of p38, these results have not been confirmed yet by the other researchers. It seems that further studies are needed to understand the mechanism of ROS in cancer.

Since the main purpose of this chapter is not to deal with the effect of ROS in tumorogenesis, we will explain the effect of ROS on DNA and DNA repair enzymes. ROS can cause direct oxidative DNA damage by increasing a cell's mutation.

Major oxidative DNA damage products including those of 8-oxo-7, 8-dihydroadenine (8oxoAde), 8-oxo-7, 8-dihydroguanine (8-oxoGua), 8-oxo-7, 8-dihydro-2'-deoxyguanosine (8-oxodG), and 5, 6-dihydroxy-5, 6-dihydrothymine as well as the ring-open lesions of 4, 6-diamino-5-formamido-pyrimidine and 2, 6-diamino-4-hydroxy-5-formamidopyrimidine [Kohen \& Nyska, 2002]. Of these oxidative products, 8-oxoGua is known to be a biomarker of oxidative stres and its mutagenicity in mammalian cells demonstrates an additional potential as an intermediate marker of a disease endpoint (e.g. cancer). Elevated levels of such DNA lesions have been noted in many tumor types and are strongly implicated in the etiology of cancer [Valko et al., 2006]. Approximately 50\% 
higher rates of 8-oxoGua levels have been observed in lung, breast or prostate cancer patients when compared to otherwise healthy individuals [Tudek et al., 2010]. In addition, recent investigations have showed higher endogenous levels of 8-oxoGua in tumor tissues when compared to controls, thus suggesting oxidative DNA damage as a contributing factor in cancer development [Trachootham et al., 2009]. In addition, high levels of 8oxoGua and possibly other DNA lesions are suggested as reliable risk factors associated with the transformation of benign to malignant tumors [Chen et al., 2007]. Furthermore, 8oxoGua lesions are known to induce aberrant modifications in adjacent DNA a hypothesized mechanism that significantly contributes to the genetic instability and metastatic potential of tumor cells [Valko et al., 2006]. For example, formation of 8oxoGua lesions has been shown to induce a cascade of adjacent DNA base mutations, such as GC $\rightarrow$ TA transversions in the ras oncogene [Bos, 1988] and p53 tumour suppressor gene in lung and liver cancer [Valko et al.2006, Mos, 1988, Takahashi et al., 1989]. Under normal conditions, DNA repair mechanisms include OGG1, nei-like glycosylase 1 (NEIL1), APE1, and MutY homologue (MUTYH) (Evans et al. 2004). In addition, nucleotide excision repair (NER) may also participate in the process of removing the 8-OHdG lesion [Klaunig, 2010]. Several genes involved in the processing of oxidative DNA damage have been analysed in relation to human cancer risk in molecular epidemiological studies. Among these genes, allele polymorphic variants have been found in OGG1, XRCC1, Pol b, APE1 and MUTYH, which are associated with a varying extent increased cancer risk [Canbay et al., 2010, Agachan et al., 2009, Narter et al., 2009, Attar et al., 2010]. Several SNPs within hOGG1 have been reported [Kohno et al., 1998]. As polymorphisms in this gene alter glycosylase function and an individual's ability to repair oxidatively damaged DNA, they may contribute to carcinogenesis [Boiteaux \& Radicella, 2000, Ide \& Kotera, 2004, Shao et al., 2006]. Epidemiologic studies investigating the association between the SNPs of OGG1 have led to conflicting results. The variant allele of this SNP was shown to be associated with significantly increased risk of a number of human cancers, including lung [Hung et al., 2005, Li \& Kong, 2008], esophageal [Xing et al., 2001], prostate [Xu et al., 2002], and gastric [Farinati et al., 2008] cancer but not with squamous cell carcinoma of the head and neck (SCCHN) [Zhang et al., 2004] or pancreatic cancer [McWilliams et al., 2008]. A total of eighteen polymorphisms in APE1 have been reported, among which Gln51His and Asp148Glu are the two most common SNPs. Associations between polymorphisms in APE1 and increased risk of lung, colon, breast, SCCHN, prostate, and pancreatic cancer have been reported, but with mixed results [Hung et al., 2005, Zhang et al., 2004, Goode et al., 2002, Jiao et al., 2006].

Studies relating to lung cancer and smoking have supported a potential role for ROS in cancer. Cigarette smoking is strongly linked to the aetiology of lung cancer [Hoffman \& Wynder, 1986], being shown to increase the generation of free radical species [Church \& Pryor, 1985] and elevate levels of oxidative DNA damage in human lungs [Asami et al., 1997, Agachan et al., 2009, ] and white blood cells [Kiyosawa et al., 1990, Lodovici et al., 2000], as well as to increase the repair of 8-OH-Gua [Asami et al., 1996] and lead to an increased urinary excretion of $8-\mathrm{OH}-\mathrm{dG}$ and 5-OHMeUra in smokers compared to nonsmokers [Loft et al., 1994, Pourcelot et al., 1999].

Recently ROS-mediated mutations in mitochondrial DNA (mtDNA) have emerged as an important contributor to human carcinogenesis [Freuhaug \& Meyskens, 2007]. Mutations in mitochondrial genes encoding complexes I, III, IV and V, as well as within the hypervariable 
region of mtDNA, have been identified in various human cancers. In general, mtDNA is more susceptible to oxidative damage than nuclear DNA because (i) mitochondrial DNA is not protected by histones, (ii) mitochondrial DNA repair capacity is limited, and (iii) under physiological conditions, the mitochondria converts roughly $3-5 \%$ of $\mathrm{O}_{2}$ consumed into - $\mathrm{O}_{2}-$ and subsequently $\mathrm{H}_{2} \mathrm{O}_{2}$. In addition, mtDNA is located in close proximity to the respiratory chain and thus is consequently readily exposed to ROS-induced oxidative damage. As a result, mtDNA has more than two orders of magnitude higher frequency of oxidative damage than that of nuclear DNA and significantly correlates with the development of cancer [Ralph et al., 2010].

\section{Cardiovascular disease}

It is known that DNA alterations exist in atherosclerotic tissues and may play a fundamental role in the pathogenesis of this disease [Olinski et al., 2002, De Flora et al., 1997, Lee et al., 2001]. Elevated level of 8-OH-Gua found in the lesion of the aorta wall in atherosclerotic patients may be one of the events directly involved in the development of the disease [De Flora et al., 1997]. Oxidized low-density lipoprotein (LDL) might play an important role in the development of atherosclerotic lesions [Ross, 1993]. Interestingly, it has been found that oxidized LDL downregulates enzymes that take part in the BER pathways [Chen et al., 2000]. This DNA repair mechanism is responsible for the removal of 8-OH-Gua from cellular DNA [Dianov et al., 1998]. Therefore, it is possible that oxidized LDL that contributes directly to the development of atherosclerosis, may also be responsible for the high level of $8-\mathrm{OH}-\mathrm{Gua}$ observed in blood lymphocytes [Chen et al., 2000].

\section{Neurodegenerative diseases}

Alzheimer's disease (AD), Huntington's disease and Parkinson's disease (PD) are neurodegenerative conditions, thought to be the result, in part, of chronic exposure to environmental neurotoxins, coupled with a genetic component. These diseases all have oxidative stress implicated in their pathogenesis [Lovell et al., 1999, Lezza et al., 1999, Alam et al., 1997, Zhang et al., 1999], and elevated levels of oxidative DNA damage have been measured in a broad range of neurological conditions [ Koppele et al., 1996, Alam et al., 2000]. Supportive of the studies showing elevated lesion levels are data derived from in vitro studies demonstrating that neurotransmitters such as dopamine and serotonin can generate DNA-damaging, free radical species [Spencer et. al., 1994, Wrona et al., 1998]. Overall, the role of oxidative stress in neurodegenerative disease appears undisputed. However, damage to lipid and protein, rather than DNA, appears to have been apportioned the greatest significance [Markesbery, 1999, Christen, 2000, Smith et al., 2000].

\section{Inflammatory disease}

The association between inflammation and oxidative stress is well documented [Wiseman et al., 1996, Khanna \& Shiloh, 2009], with numerous studies of inflammatory conditions or infections reporting elevated levels of 8-OH-dG: hepatitis [Shimoda et al., 1994], hepatitis C infection [Farinati et al., 1999], and atopic dermatitis. An important source of the ROS are the bactericidal species $\left(\mathrm{O}_{2}{ }^{--}\right.$and $\left.\mathrm{H}_{2} \mathrm{O}_{2}\right)$, generated from the respiratory burst of invading neutrophils, macrophages, and eosinophils damaging surrounding tissue. Chronic inflammation, and the accompanying oxidative stress, has been closely linked to the pathogenesis of autoimmune diseases such as rheumatoid arthritis [Bashir et.al, 1993] and systemic lupus erythematosus [Lunec et.al., 1994], with free radical production resulting, not 
only in connective tissue damage, but also modified biomolecules being exposed to the systemic circulation, postulated to be the antigen driving autoantibody production [Weitzman \& Gordon, 1990].

Elevated DNA levels of 8-OH-dG have been reported in lymphocytes from patients with RA, SLE, vasculitis or Behcet's disease. These same lymphocytes, from RA and SLE patients, also display increased sensitivity to hydrogen peroxide-induced cytotoxicity [Bashir et al., 1993].

\section{Ischemia-reperfusion injury}

The literature provides a growing number of reports in which levels of oxidative DNA damage are elevated in post-ischaemia-reperfusion. Elevated levels of urinary 8-OH-dG or dTg were reported following liver transplantation, which proposed to be due to ischemiareperfusion or reoxygenation injury [Thier et al., 1999, Loft et al., 1995]. Ischaemiareperfusion injury is a significant factor affecting morbidity and mortality following bypass and transplantation surgery, haemorrhagic or septic shock, myocardial infarction and multiple organ failure. During the period of ischaemia, xanthine dehydrogenase is converted to xanthine oxidase. Upon reperfusion, there is a "burst" of xanthine oxidase activity which, rather than transferring electrons to NAD+, transfers them to $\mathrm{O}_{2}$, generating superoxide, with the subsequent potential for generating other ROS and hence DNA damage. Endogenous levels of xanthine dehydrogenase vary from organ to organ and hence ischemia-reperfusion injury might be more relevant to some tissues than others. Human leukocytes appear to be sensitive to the genotoxic effects of ischemia-reperfusion (163) and therefore represent a potential surrogate tissue in which to study the effects of ischemiareperfusion that have affected a less accessible tissue.

\section{Aging}

Major theories of aging are grouped under two categories: damage accumulation aging and developmentally programmed aging. However, a developing (emerging) hypothesis described as the free radical theory of aging appears to have adopted elements of the former theories. The basis of the Harman's theory [Harman, 1956] suggested that aging occurs through the gradual accumulation of free radical damage to biomolecules. With age, antioxidant defences fail to scavenge all potentially damaging radical species that result in the insidious accumulation of damage and gradual loss of function [Beckman et al., 1998]. One of the few focussing upon DNA damage, is a report of an age-related increase in serum 8-OH-dG in apparently disease-free individuals over an age range of 15-91 years [Rattan et al., 1995]. Although this same trend was not evident in the urinary 8-OH-dG output of infants, a gradual increase was noted over the first month postpartum, which mirrored the velocity growth curve [Drury et al., 1998].

The accumulation of lesions can, in part, be explained by the discovery that DNA repair capability correlates with species-specific life span [168]. Furthermore, repair activity appears to decline with age, resulting in the persistence of damage and a subsequent increase in replication errors [Hirano et al., 1995].

\section{Conclusion}

Although there is association between oxidative DNA damage and diseases, elucidation of the role of oxidative DNA damage requires much more work. It is well known that DNA 
repair enzymes are important for oxidative DNA damage. If individual spesific biomarkers related DNA repair enzyme are found, new treatmant strategies would be developed to cure disease related oxidative DNA damage.

\section{References}

Adachi Y, Shibai Y, Mitsushita J, Shang WH, Hirose K, Kamata T. 2008. Oncogenic Ras upregulates NADPH oxidase 1 gene expres s ion through MEK-ERK-dependent phosphorylation of GATA-6. Oncogene 27: 4921-4932

Adly, AAM. 2010. Oxidative stress and disease: An updated review. Res. J. Immunol., 3: 129145.

Agaçhan B, Küçükhüseyin O, Aksoy P, Turna A, Yaylim I, Görmüs U, Ergen A, Zeybek U, Dalan B, Isbir T. 2009. Apurinic/apyrimidinic endonuclease (APE1) gene polymorphisms and lung cancer risk in relation to tobacco smoking. Anticancer Res., 29(6):2417-20.

Alam ZI, Jenner A, Daniel SE, Lees AJ, Cairns N, Marsden CD, Jenner P, Halliwell B. 1997. Oxidative DNA damage in the Parkinsonian brain: an apparent selective increase in 8-hydroxyguanine levels in substantia nigra, J. Neurochem. , 1196-1203.

Alam ZI, Halliwell B, Jenner P. 2000. No evidence for increased oxidative damage to lipids, proteins, or DNA in Huntington's disease. J. Neurochem., 840-846

Altman SA, Zastawny TH, Randers-Eichhorn L, Cacciuttolo MA, Akman SA, Dizdaroglu M., Rao G. 1995. Formation of DNA-protein cross-links in cultured mammalian cells upon treatment with iron ions. Free Radical Biol. Med., 897-902.

Asami S, Manabe H, Miyake J, Tsurudome Y, Hirano T, Yamaguchi R, Itoh H, Kasai H. 1997. Cigarette smoking induces an increase in oxidative DNA damage, 8hydroxydeoxyguanosine, in a central site of the human lung. Carcinogenesis, 18;1763-1766.

Asami S, Hirano T, Yamaguchi R, Tomioka Y, Itoh H, Kasai H. 1996. Increase of a type of oxidative DNA damage, 8-hydroxyguanine, and its repair activity in human leukocytes by cigarette smoking. Cancer Res., 56; 2546-2549.

Attar R, Cacina C, Sozen S, Attar E, Agachan B. 2010. DNA repair genes in endometriosis. Genet Mol Res., 6;9(2):629-36.

Babior BM.2000. The NADPH oxidase of endothelial cells. IUBMB Life, 50;267-269.

Bashir S, Harris G, Denman MA, Blake DR, Winyard PG. 1993. Oxidative DNA damage and cellular sensitivity to oxidative stress in human autoimmune diseases. Ann. Rheum. Dis., 52; 659-666.

Beckman JS, Ischiropoulos H, Zhu L, van der Woerd M, Smith C, Chen J, Harrison J, Martin JC, Tsai M.1992. Kinetics of superoxide dismutase- and iron-catalyzed nitration of phenolics by peroxynitrite. Arch Biochem Biophys., 298:438-445.

Beckman KB and Ames BN. 1998. The free radical theory of aging matures. Physiol. Rev., 78, 547-581.

Behrend, R. and Roosen, O. 1889. Synthese der Harnsa“ure. Liebigs Ann.Chem., 251, 235-256.

Bielski BHJ and Cabelli DE. 1995. Superoxide and hydroxyl radical chemistry in aqueous solution. In: Active Oxygen in Chemistry, Foote CS, Valentine JS, Greenberg A, Liebman JF (eds). Chapman and Hall, London, pp. 66-104.

Boiteux S and Radicella JP.2000. The human OGG1 gene: Structure, functions, and its implication in the process of carcinogenesis. Arch Biochem Biophys., 377, 1-8. 
Bos JL. 1988. The ras gene family and human carcinogenesis.Mutat. Res., 195;255-271.

Breen AP and Murphy JA.1995. Reactions of hydroxyl radicals with DNA. Free Radic. Biol. Med., 18, 1033-1077

Cadenas E and Davies KJ. 2000. Mitochondrial free radical generation, oxidative stress, and aging. Free Radic Biol Med., 29(3-4):222-30.

Cadet J, Berger M, Decarroz C, Mouret JF, Vanlier JE, Wagner RJ. 1991.Photoinduced and radio-induced radical oxidation of the purine and pyrimidine bases of nucleic acids. J. Chim. Phys. Phys.-Chim. Biol. 88;1021-1042.

Cadet J, Berger M, Buchko GW, Joshi PC, Raoul S., Ravanat J-L. 1994.2, 2-Diamino-4-[3, 5-diO-acetyl-2-deoxy-betad-erythrosepentofuranosyl) amino]-5-(2H)-oxazolone-a novel and predominant radical oxidation product of 3_, 5_-di-O-acetyl-2_deoxyguanosine. J. Am. Chem. Soc. 116;7403-7404.

Canbay E, Agachan B, Gulluoglu M, Isbir T, Balik E, Yamaner S, Bulut T, Cacina C, Eraltan IY, Yilmaz A, Bugra D. 2010.Possible associations of APE1 polymorphism with susceptibility and HOGG1 polymorphism with prognosis in gastric cancer. Anticancer Res., 30(4):1359-64.

Candeias LP, Steenken S. 2000. Reaction of HO. with Guanine Derivatives in Aqueous Solution: Formation of Two Different Redox-Active OH-Adduct Radicals and Their Unimolecular Transformation Reactions. Properties of G(-H).Chemistry - A European Journal, 6: 475-484

Chen HI, Liou SH, Ho SF, Wu KY, Sun CW, Chen MF, Cheng LC, Shih TS, Loh CH.2007. Oxidative DNA damage estimated by plasma 8-hydroxyxeoxyguanosine (8$\mathrm{OHdG}$ ): influence of 4, 4'-methylenebis (2-chloroaniline) exposure and smoking. J. Occup. Health. 49, pp. 389-398

Chen KH, Srivastava DK, Singhal RK, Jacob S, Ahmed AE, Wilson SH. 2000.Modulation of base excision repair by low density lipoprotein, oxidized low density lipoprotein and antioxidants in mouse monocytes. Carcinogenesis, 21:1017-1022.

Christen Y. 2000.Oxidative stress and Alzheimer disease. Am. J. Clin. Nutr. 71;621S-629S.

Church DF, Pryor WA. 1985. Free-radical chemistry of cigarette smoke and its toxicological implications. Environ. Health Perspect. 64;111-126.

Colton CA , Gilbert DL. 1999. Reactive Oxygen Species in Biological Systems: An Interdisciplinary Approach. Springer US. 740. Hardcover

Cooke MS, Evans MD, Dizdaroglu M, Lunec J. 2003.Oxidative DNA damage: mechanisms, mutation, and disease. FASEB J., 17(10):1195-214.

De Flora S, Izzotti A, Walsh D, Degan P, Petrilli GL, Lewtas J. 1997.Molecular epidemiology of atherosclerosis. FASEB J, .11:1021-1031.

Demple B, Herman T, Chen DS. 1991.Cloning and expression of APE, the cDNA encoding the major human apurinic enodnuclease: Definition of a family of DNA repair enzymes. Proc Natl Acad Sci U S A, 88:11450-54.

Dianov G, Bischoff C, Piotrowski J, Bohr VA.1998. Repair pathways for processing of 8oxoguanine in DNA by mammalian cell extracts. J. Biol. Chem., 273:33811-33816.

Dirksen ML, Blakely WF, Holwitt E, Dizdaroglu, M.1988.Effect of DNA conformation on the hydroxyl radicalinduced formation of 8, 5_-cyclopurine 2_-deoxyribonucleoside residues in DNA. Int. J. Radiat. Biol., 54, 195-204 
Dizdaroglu M, Bauche C, Rodriguez H, Laval J. 2000.Novel substrates of Escherichia coli Nth protein and its kinetics for excision of modified bases from DNA damaged by free radicals. Biochemistry, 39;5586-5592.

Dizdaroglu M, Gajewski E, Reddy P, Margolis SA.1989. Structure of a hydroxyl radical induced DNA-protein cross-link involving thymine and tyrosine in nucleohistone.Biochemistry, 28; 3625-3628.

Dizdaroglu M.1998.Mechanisms of free radical damage to DNA, in: O.I. Aruoma (Ed.), DNA \& Free Radicals: Techniques, Mechanisms \& Applications, OICA International, Saint Lucia, pp. 3-26.

Dizdaroglu M.1993. Quantitative determination of oxidative base damage in DNA by stable isotope-dilution mass spectrometry, FEBS Lett., 315;1-6.

Dizdaroglu M.1986.Free-radical-induced formation of an 8, 5_-cyclo-2_-deoxyguanosine moiety in deoxyribonucleic acid. Biochem. J, . 238, 247-254

Dizdaroglu M. 1992. Oxidative damage to DNA in mammalian chromatin. Mutat. Res, 275, 331-342.

Dizdaroglu M, Dirksen, ML, Jiang HX, Robbins JH. 1987. Ionizing-radiation-induced damage in the DNA of cultured human cells. Identification of 8, 5-cyclo-2deoxyguanosine. Biochem. J., 241, 929-932

Dizdaroglu M, Laval J, Boiteux S.1993.Substrate specificity of the Escherichia coli endonuclease III: excision of thymine- and cytosine-derived lesions in DNA produced by radiation-generated free radicals. Biochemistry, 32, 12105-12111.

Drury JA, Jeffers G, Cooke RW.1998.Urinary 8-hydroxydeoxyguanosine in infants and children. Free Radic. Res. 28, 423-428

Duarte V, Gasparutto D, Jaquinod M, Cadet J.2000. In vitro DNA synthesis opposite oxazolone and repair of this DNA damage using modified oligonucleotides. $\mathrm{Nucl}$. Acids Res. 28;1555-1563.

Evans MD, Dizdaroglu M, Cooke MS. 2004.Oxidative DNA damage and disease: induction, repair and significance. Mutat Res. 567(1):1-61.

Farinati F, Cardin R, Bortolami M, Nitti D, Basso D., de Bernard M., Cassaro M., Sergio A, Rugge, M. 2008. Oxidative DNA damage in gastric cancer: CagA status and OGG1 gene polymorphism. Int J Cancer. , 123, 51-5.

Farinati, F., Cardin, R., Degan, P., De Maria, N., Floyd, R. A., Van Thiel, D. H., and Naccarato, R. (1999) Oxidative DNA damage in circulating leukocytes occurs as an early event in chronic HCV infection. Free Radic. Biol., Med. 27, 1284-1291

Forman HJ, Boveris A. 1982. Superoxide radical and hydrogen peroxide in mitochondria, in: WA Pryor (Ed.), Free Radicals in Biology, Vol. V, New York: Academic Press, pp. 6590

Frenkel K. 1992. Carcinogen-mediated oxidant formation and oxidative DNA damage. Pharmacol. Ther. 53, 127-166

Fruehaug JP, Meyskens FL. 2007.Reactive oxygen species: a breath of life of death? Clin. Cancer Res. 13;789-794.

Galaris D, Skiada V, Barbouti A.2008. Redox signaling and cancer: the role of 'labile' iron, Cancer Lett. 266;21-29.

Goode EL, Ulrich CM, Potter JD.2002. Polymorphisms in DNA repair genes and associations with cancer risk. Cancer Epidemiol Biomarkers Prev., 11, 1513-30. 
Halliwell B, Gutteridge JM. 1999.Free Radicals in Biology and Medicine, third edition. Oxford University Press, Midsomer Norton, Avon, England.

Harman D.1956. Aging: a theory based on free radical and radiation chemistry. J. Gerontol, . 11, 298-300

Hart RW, Setlow RB.1974. Correlation between deoxyribonucleic acid excision-repair and life-span in a number of mammalian species. Proc. Natl. Acad. Sci. USA, 71;21692173.

Hashiguchi K, Bohr VA, de Souza-Pinto NC. 2004.Oxidative stress and mitochondrial DNA repair: implications for NRTIs induced DNA damage. Mitochondrion., 4(2-3):215-22.

Hashiguchi K, Stuart JA, de Souza-Pinto NC, Bohr VA. 2004.The C-terminal aO helix of human Ogg1 is essential for 8-oxoguanine DNA glycosylase activity: The mitochondrial $\beta$-Ogg1 lacks this domain and does not have glycosylase activity. Nucleic Acids Res., 32:5596-5608.

Hazra TK, Das A, Das S.2007.Oxidative DNA damage repair in mammalian cells: A new perspective. DNA Repair, 6: 470-480.

Hedge ML, Hazra TK, Mitra S. 2008.Early steps in the DNA base excision/single-strand interruption repair pathway in mammalian cells. Cell Res. 18:27-47.

Heyworth PG, Knaus UG, Settleman J, Curnutte JT, Bokoch GM. Regulation of NADPH oxidase activity by Rac GTPase activating protein(s). Mol Biol Cell 1993; 4: 1217-1223

Hirano T, Yamaguchi Y, Hirano H, Kasai H. 1995.Ageassociated change of 8hydroxyguanine repair activity in cultured human fibroblasts.Biochem. Biophys. Res.Commun., 214;1157-1162.

Hoffmann D, Wynder EL. 1986. Chemical constituents and bioactivity of tobacco smoke, IARC Sci. Publ., 74; 145-165.

Hsu IC, Metcalf RA, Sun T, Welsh JA, Wang NJ, Harris CC.1991. Mutational hotspot in the p53 gene in human hepatocellular carcinomas.Nature, 350;427-428.

Hung RJ, Hall J, Brennan P, Boffetta P. 2005. Genetic polymorphisms in the base excision repair pathway and cancer risk: A HuGE review.Am J Epidemiol, 162, 925-42.

Ide H., Kotera M. 2004. Human DNA glycosylases involved in the repair of oxidatively damaged DNA. Biol Pharm Bull, 27, 480-5.

Imlay JA, Chin SM, Linn S. 1988. Toxic DNA damage by hydrogen peroxide through the Fenton reaction in vivo and in vitro. Science, 240; 640-642.

Jayaraman L, Murthy KGK, Zhu C.1997. Identification of redox/repair protein Ref-1 as a potent activator of p53. Genes Dev., 11:558-70.

Jiao L., Bondy ML, Hassan MM, Wolff RA, Evans DB, Abbruzzese JL., Li D. 2006. Selected polymorphisms of DNA repair genes and risk of pancreatic cancer. Cancer Detect Prev, 30, 284-91

Kadara H, Tahara E, Kim HJ, Lotan D, Myers J, Lotan R. Involvement of Rac in fenretinideinduced apoptosis. Cancer Res 2008; 68: 4416-4423

Kaguni LS.2004. DNA polymerase gamma, the mitochondrial replicase.Annu Rev Biochem, 73:293-320.

Kamata H, Hirata H.1999.Redox regulation of cellular signalling. Cell Signal, 11:1-14.

Kavli B, Otterlei M, Slupphaug G, Krokan HE. 2007. Uracil in DNA - general mutagen, but normal intermediate in acquired immunity. DNA Repair (Amst), 6, 505-516.

Khanna KK, Shiloh Y.2009.The DNA Damage Response: Implications on Cancer Formation and Treatment. Springer Publication. XII, 449 p. 
King PA, Anderson VE, Edwards JO, Gustafson G, Plumb RC, Sugas JW. 1992. A stable solid that generates hydroxyl radical upon dissolution in aqueous solution: reaction with proteins and nucleic acids. J Am Chem Soc, 114:5430 -5432.

Kiyosawa H, Suko M, Okudaira H, Murata K, Miyamoto T, Chung MH, Kasai H, Nishimura S.1990. Cigarette smoking induces formation of 8-hydroxydeoxyguanosine, one of the oxidative DNA damages in human peripheral leukocytes. Free Radical Res. Commun. 11;23-27.

Klaunig J, Kamendulis LM.2004. The role of oxidative stress in carcinogenesis.Annu.Rev. Pharmacol. Toxicol. 44; 239-267.

Klaunig JE, Kamendulis LM, Hocevar BA.2010. Oxidative stress and oxidative damage in carcinogenesis. Toxicol Pathol., 38(1):96-109.

Klungland A, Bjelland S. 2007.Oxidative damage to purines in DNA: role of mammalian Ogg1. DNA Repair (Amst), 6, 481-488.

Kohen R, Nyska A. 2002. Oxidation of biological systems: oxidative stress phenomena, antioxidants, redox reactions, and methods for their quantification. Toxicol Pathol. , 30(6):620-50.

Kohno T, Shinmura K, Tosaka M, Tani M, Kim, SR, Sugimura H, Nohmi T, Kasai H, Yokota J. 1998. Genetic polymorphisms and alternative splicing of the hOGG1 gene, that is involved in the repair of 8-hydroxyguanine in damaged DNA. Oncogene, 16, 321925.

Koppele J, Lucassen PJ, Sakkee AN, van Asten JG, Ravid R, Swaab DF, van Bezooijen CFA.1996. 8-OHdG levels in brain do not indicate oxidative DNA damage in Alzheimer's disease. Neurobiol. Aging, 17, 819-826

Krokan HE, Nilsen H, Skorpen F, et al.2000 Base excision repair of DNA in mammalian cells. FEBS Lett, 476: 73-77.

Lakshmipathy U, Campbell C.1999.The human DNA ligase III gene encodes nuclear and mitochondrial proteins. Mol Cell Biol, 19: 3869-3876.

Lakshmipathy U, Campbell C.2001.Antisense-mediated decrease in DNA ligase III expression results in reduced mitochondrial DNA integrity. Nucleic Acids Res., 29:668-676.

Lee KW, Lee HJ.2006. Biphasic effects of dietary antioxidants on oxidative stress- mediated carcinogenesis.Mech. Ageing Dev. 127; 424-431.

Lee SH, Blair IA.2001. Oxidative DNA damage and cardiovascular disease. Trends Cardiovasc. Med., 11:148-155.

Lezza A, Mecocci P, Cormio A, Flint Beal M, Cherubini A, Cantatore P, Senin U, Gadaleta MN. 1999.Areaspecific differences in OH8dG and mtDNA4977 levels in Alzheimer disease patients and aged controls.J. Anti-aging Med. 2 ;209-215.

Li W, Kong AN. 2008. Molecular mechanisms of Nrf2-mediated antioxidant response. Mol Carcinog, 48, 91-104.

Lindahl T.1974. An N-glycosidase from Escherichia coli that releases free uracil from DNAcontaining deaminated cytosine residues. Proc. Natl. Acad. Sci. USA, 71, 36493653

Lodovici M, Casalini C, Cariaggi R, Michelucci L, Dolara P.2000.Levels of 8hydroxydeoxyguanosine as a marker of DNA damage in human leukocytes.Free Radical Biol. Med., 28;13-17. 
Loft S, Astrup A, Buemann B, Poulsen HE.1994. Oxidative DNA damage correlates with oxygen consumption in humans, Faseb J. 8;534-537.

Loft S, Larsen PN, Rasmussen A, Fischer-Nielsen A, Bondesen S, Kirkegaard P, Rasmussen LS, Ejlersen E, Tornoe K, Bergholdt, R. 1995. Oxidative DNA damage after transplantation of the liver and small intestine in pigs. Transplantation, 59, 16-20

Longley MJ, Prasad R, Srivastava DK, Wilson SH, Copeland WC. 1998. Identification of 5=deoxyribose phosphate lyase activity in human DNA polymerase gamma and its role in mitochondrial base excision repair in vitro. Proc Natl Acad Sci U $S$ A, 95:12244-12248.

Lovell MA, Gabbita SP, . Markesbery WR.1999. Increased DNA oxidation and decreased levels of repair products in Alzheimer's disease ventricular CSF. J. Neurochem. 72; 771-776.

Lunec J, Herbert K, Blount S, Griffiths HR, Emery P.1994. 8-Hydroxydeoxyguanosine. A marker of oxidative DNA damage in systemic lupus erythematosus. FEBS Lett. 348 ;131-138.

Markesbery WR. 1999.The role of oxidative stress in Alzheimer disease.Arch. Neurol. 56; 1449-1452.

Marnett LJ.2000. Oxyradicals and DNA damage. Carcinogenesis, 21:361-70.

McWilliams RR., Bamlet WR, Cunningham JM, Goode EL, de Andrade M, Boardman LA, Petersen, GM. 2008. Polymorphisms in DNA repair genes, smoking, and pancreatic adenocarcinoma risk. Cancer Res. 68, 4928-35.

Meira LB, Devaraj S, Kisby GE.2001.Heterozygosity for the mouse Apex gene result in phenotypes associated with oxidative stress. Cancer Res, 61:5552-57.

Mena S, Ortega A, Estrela J.2009. Oxidative stress in environmental-induced carcinogenesis. Mutat. Res. $674 ; 36-44$.

Michalik V, Spotheim Maurizot M, Charlier M.1995. Calculation of hydroxyl radical attack on different forms of DNA. J Biomol Struct Dyn, 13:565-575.

Moller P, Folkmann JK, Forchhammer L, Brauner EV, Danielsen P, Rison L, Loft S. 2008.Air pollution, oxidative damage to DNA, and carcinogenesis. Cancer Lett.;266;84-97.

Moreno JJ, Pryor WA (1992) Inactivation of alpha 1-proteinase inhibitor by peroxynitrite. Chem Res Toxicol 5:425-431.

Nackerdien Z, Rao G., Cacciuttolo MA, Gajewski E, Dizdaroglu M.1991. Chemical nature of DNA-protein cross-links produced in mammalian chromatin by hydrogen peroxide in the presence of iron or copper ions, Biochemistry 30; 4873-4879.

Nackerdien Z, Kasprzak KS, Rao G, Halliwell B, Dizdaroglu M.1991. Nickel(II)- and cobalt(II)-dependent damage by hydrogen peroxide to the DNA bases in isolated human chromatin. Cancer Res. 51, 5837-5842.

Narter KF, Ergen A, Agaçhan B, Görmüs U, Timirci O, Isbir T. 2009.Bladder cancer and polymorphisms of DNA repair genes (XRCC1, XRCC3, XPD, XPG, APE1, hOGG1). Anticancer Res., 29(4):1389-93.

Nohl H, Hegner D.1978. Do mitochondria produce oxygen radicals in vivo? Eur J Biochem, 82:563-567.

O'Connor TR, Laval J. 1989. Physical association of the 2, 6-diamino-4-hydroxy-5Nformamidopyrimidine-DNA glycosylase of Escherichia coli and an activity nicking DNA at apurinic/apyrimidinic sites. Proc. Natl. Acad. Sci. USA, 86, 5222-5226. 
O'Neill P.1983. Pulse radiolytic study of the interaction of thiols and ascorbate with $\mathrm{OH}$ adducts of dGMP and dG: implications for DNA repair processes. Radiat. Res., 96 ; 198-210.

Olinski R, Gackowski D, Foksinski M, Rozalski R, Roszkowski K, Jaruga P.2002.Oxidative DNA damage: assessment of the role in carcinogenesis, atherosclerosis, and acquired immunodeficiency syndrome. Free Radic Biol Med. 33(2):192-200.

Olinski R, Nackerdien Z, Dizdaroglu M.1992. DNA-protein cross-linking between thymine and tyrosine in chromatin of gamma-irradiated or $\mathrm{H}_{2} \mathrm{O}_{2}$-treated cultured human cells.Arch. Biochem. Biophys. 297; 139-143.

O'Neill P, Chapman PW. 1985. Potential repair of free radical adducts of dGMP and dG by a series of reductants. A pulse radiolytic study. Int. J. Radiat. Biol. Relat. Stud. Phys. Chem. Med., 47, 71-80

Packer MA, Murphy MP. 1994. Peroxynitrite causes calcium efflux from mitochondria which is prevented by Cyclosporin A. FEBS Lett., 345:237-240.

Pan JS, Hong MZ, Ren JL. Reactive oxygen species: a double-edged sword in oncogenesis. World J Gastroenterol. 2009 Apr 14;15(14):1702-7.

Pourcelot S, Faure H, Firoozi F, Ducros V, Tripier M, Hee J, Cadet J, Favier A.1999. Urinary 8-oxo-7, 8-dihydro-2_-deoxyguanosine and 5-(hydroxymethyl) uracil in smokers. Free Radical Res., 30; 173-180.

Radi R, Beckman JS, Bush KM, Freeman BA. 1991a. Peroxynitrite-induced membrane lipid peroxidation: the cytotoxic potential of superoxide and nitric oxide. Arch Biochem Biophys., 288:481-487.

Radi R, Beckman JS, Bush KM, Freeman BA. 1991b. Peroxynitrite oxidation of sulfhydryls. The cytotoxic potential of superoxide and nitric oxide. J Biol Chem., 266:4244-4250.

Radi R, RodriguezM, Castro L, Telleri R.1994. Inhibition of mitochondrial electron transport by peroxynitrite. Arch Biochem Biophys., 308:89-95.

Raha S, Robinson BH. 2000. Mitochondria, oxygen free radicals, disease and ageing. Trends Biochem. Sci. 25, 502-508.

Ralph SJ, Enríquez SR, Neuzil J, Saavedra E, Sánchez RM. 2010. The causes of cancer revisited: "mitochondrial malignancy" and ROS-induced oncogenic transformation -Why mitochondria are targets for cancer therapy. Mol. Aspects Med. 31; 145-170.

Raoul S, Berger M, Buchko GW, Joshi PC, Morin B, Weinfeld M, Cadet J.1996. H-1, C-13 and $\mathrm{N}-15$ nuclear magnetic resonance analysis and chemical features of the two main radical oxidation products of 2_-deoxyguanosine: oxazolone and imidazolone nucleosides. J. Chem. Soc. Perkin Trans., 371-381.

Rattan S, Siboska GE, Wikmar FP, Clark BFC, Woolley P. 1995. Levels of oxidative DNA damage product 8-hydroxy-2_-deoxyguanosine in human serum increases with age. Med. Sci. Res. 23, 469-470

Robertson AB, Klungland A, Rognes T, Leiros I. 2009.DNA repair in mammalian cells: Base excision repair: the long and short of it. Cell Mol Life Sci., 66(6):981-93.

Ross R. 1993. Rous-Whipple Award Lecture. Atherosclerosis: a defense mechanism gone awry. Am J Pathol., 143: 987-1002

Schafer FQ, Buettner GR. 2001. Redox environments of the cell as viewed through the redox state of the glutathione disulfide/glutathione couple. Free Rad Biol Med., 30: 11911212. 
Sedgwick B, Bates PA, Paik J, Jacobs SC, Lindahl T. 2007. Repair of alkylated DNA: recent advances. DNA Repair (Amst) 6, 429-442.

Sen S , Chakraborty R, Sridhar C, Reddy YSR, De B. 2010. Free Radicals, Antioxidants, Diseases and Phytomedicines: Current Status and Future Prospect. International Journal of Pharmaceutical Sciences Review and Research, Volume 3, Issue 1, p.91-100

Shao L, Hittelman WN, Lin J, Yang H, Ajani JA., Wu X. 2006.Deficiency of cell cycle checkpoints and DNA repair system predispose individuals to esophageal cancer. Mutat Res., 602, 143-50.

Shimoda R, Nagashima M., Sakamoto M, Yamaguchi N, Hirohashi S, Yokota J, Kasai H. 1994. Increased formation of oxidative DNA damage, 8-hydroxydeoxyguanosine, in human livers with chronic hepatitis. Cancer Res., 54, 3171-3172

Smith MA, Rottkamp CA, Nunomura A, Raina AK, Perry G.2000. Oxidative stress in Alzheimer's disease. Biochim.Biophys. Acta, 1502;139-144.

Sohal RS.1997. Mitochondria generate superoxide anion radicals and hydrogen peroxide. FASEB J 11:1269-1270.

von Sonntag C. 1987. The Chemical Basis of Radiation Biology. Taylor and Francis, London, 1987, p. 57

Spencer JP, Jenner A, Aruoma OI, Evans P J, Kaur H., Dexter DT, Jenner P, Lees AJ, Marsden DC, Halliwell B. 1994.Intense oxidative DNA damage promoted by L-dopa and its metabolites. Implications for neurodegenerative disease. FEBS Lett., 353, 246-250

Steenken S.1989. Purine bases, nucleosides, and nucleotides:aqueous solution redox Chemistry and transformation reactions of their radical cations and $\mathrm{e}^{-}$and $\mathrm{OH}$ adducts.Chem. Rev. 89;503-520.

Steenken S. 1987. Addition-elimination paths in electrontransfer reactions between radicals and molecules. J. Chem. Soc. Faraday Trans. I, 83, 113-124

Sultan SM, Ioannou Y, Isenberg DA. 2000. Is there an association of malignancy with systemic lupus erythematosus? An analysis of 276 patients under long-term review. Rheumatology (Oxford), 39, 1147-1152

Takahashi T, Tada M, Igarashi S, et al. Aprataxin, causative gene product for EAOH/AOA1, repairs DNA single-strand breaks with damaged 3'-phosphate and 3'phosphoglycolate ends. Nucleic Acids Res 2007;35:3797-3809.

Takahashi T, Nau MM, Chiba I, Birrer MJ, Rosenberg RK, Vinocour M, Levitt M, Pass H, Gazdar AF, . Minna JD.1989. p53: a frequent target for genetic abnormalities in lung cancer.Science, 246 ;491-494.

Teoule R. 1987. Radiation-induced DNA damage and its repair. Int. J. Radiat. Biol. Relat. Stud. Phys. Chem. Med., 51, 573-589

Thier R, Bruning T, Kocher K, Blaszkewicz M, Makropoulos V, Sundberg A, Bolt HM.1999. Determination of urinary thymidine glycol using affinity chromatography, HPLC and post-column reaction detection: a biomarker of oxidative DNA damage upon kidney transplantation. Arch. Toxicol., 73, 479-484

Toyokuni S, Mori T, Hiai H, Dizdaroglu M.1995.Treatment of Wistar rats with a renal carcinogen, ferric nitrilotriacetate, causes DNA-protein cross-linking between thymine and tyrosine in their renal chromatin. Int. J. Cancer, 62;309-313.

Trachootham D, Alexander J, Huang P.2009. Targeting cancer cells by ROS-mediated mechanism: a radical therapeutic approach? Nat. Rev. 8;579-591. 
Tudek B, Winczura A, Janik J, Siomek A, Foksinski M, Olinski R.2010. Involvement of oxidatively damaged DNA and repair in cancer development and aging. Am. J. Transl. Res., 2; 254-284.

Ushio-Fukai M, Nakamura Y.2008. Reactive oxygen species and angiogenesis:NADPH oxidase as target for cancer therapy. Cancer Lett. 266; 37-52.

Valko M, Rhodes CJ, Moncol J, Izakovic M, Mazur M.2006. Free radicals, metals and antioxidants in oxidative stress-induced cancer, Chem. Biol. Interact. $160 ; 1-40$.

Vieira AJSC, Steenken S. 1990. Pattern of $\mathrm{OH}$ radical reaction with adenine and its nucleosides and nucleotides. Characterisation of two types of isomeric $\mathrm{OH}$ adduct and their unimolecular transformation reactions. J. Am. Chem. Soc., 112, 6986-6994

Wagner JR, Van Lier JE, Berger M, Cadet, J. 1994. Thymidine hydroperoxides: structural assignments, conformational features and thermal decomposition in water. J. Am. Chem. Soc, . 116, 2235-2242

Weissman L, de Souza-Pinto NC, Stevnsner T, Bohr VA. 2007. DNA repair, mitochondria, and neurodegeneration. Neuroscience, 145(4):1318-29.

Weitzman SA, Gordon LI. 1990. Inflammation and cancer: role of phagocyte-generated oxidants in carcinogenesis. Blood, 76, 655-663

Willy C, Dahouk S, Starck C, Kaffenberger W, Gerngross H, Plappert UG. 2000. DNA damage in human leukocytes after ischemia/reperfusion injury. Free Radic. Biol. Med, . 28, 1-12

Winters TA, Henner WD, Russel PS, et al. 1994.Removal of 3'-phosphoglycolate from DNA strand-break damage in an oligonucleotide substrate by recombinant human apurinic/apyrimidinic endonuclease. Nucleic Acids Res, 22:18866-73.

Wiseman H, Halliwell B.1996. Damage to DNA by reactive oxygen and nitrogen species: role in inflammatory disease and progression to cancer. Biochem. J. , 313, 17-29

Wood RD, Mitchell M, Sgouros J, Lindahl T. 2001.Human DNA repair genes. Science, 291:1284-9.

Wrona MZ, Dryhurst G. 1998. Oxidation of serotonin by superoxide radical: implications to neurodegenerative brain disorders. Chem. Res. Toxicol., 11, 639-650

Wu D, Cederbaum AI.2003.Alcohol, oxidative stress and free radical damage. Alcohol Res. Health, 27; 277-284.

Xing DY, Tan W, Song N, Lin DX. 2001. Ser326Cys polymorphism in hOGG1 gene and risk of esophageal cancer in a Chinese population.Int J Cancer, 95, 140-43.

$\mathrm{Xu}$ J, Zheng SL, Turner A, Isaacs SD, Wiley KE, Hawkins GA, Chang BL, Bleecker ER., Walsh PC, Meyers, DA, Isaacs WB.2002. Associations between hOGG1 sequence variants and prostate cancer susceptibility. Cancer Res, 62, 2253-57.

Yamasaki I, Piette LH.1991. EPR spin trapping study on the oxidizing species formed in the reaction of the ferrous ion with hydrogen peroxide. J Am Chem Soc , 113:75887593.

Zhang J, Perry G, Smith MA, Robertson D, Olson SJ, Graham DG, Montine TJ.1999. Parkinson's disease is associated with oxidative damage to cytoplasmic DNA and RNA in substantia nigra neurons. Am. J. Pathol. 154 ;1423- 1429.

Zhang Z, Shi Q, Sturgis EM, Spitz MR, Hong WK., Wei, Q.2004. Thymidylate synthase 5'and $3^{\prime}$-untranslated region polymorphismsassociated with risk and progression of squamous cell carcinoma of the head and neck. Clin Cancer Res, 10, 7903-10. 
Ziech D, Franco R, Georgakilas AG, Georgakila S, Malamou-Mitsi V, Schoneveld O, Pappa A, Panayiotidis MI. 2010.The role of reactive oxygen species and oxidative stress in environmental carcinogenesis and biomarker development. Chem Biol Interact. , 188(2):334-9.

Ziech D, Franco R, Pappa A, Panayiotidis MI.2011. Reactive Oxygen Species (ROS)--Induced genetic and epigenetic alterations in human carcinogenesis. Mutat Res., Mar 16. 


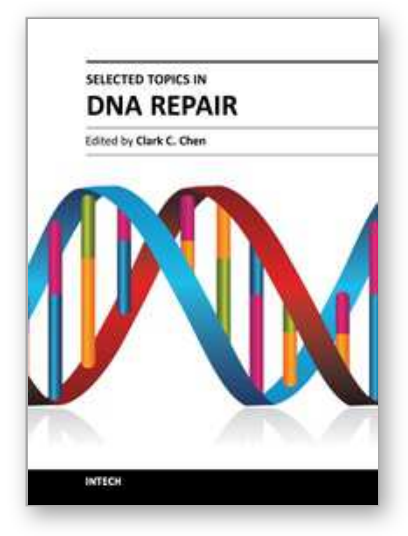

\author{
Selected Topics in DNA Repair \\ Edited by Prof. Clark Chen
}

ISBN 978-953-307-606-5

Hard cover, 572 pages

Publisher InTech

Published online 26, October, 2011

Published in print edition October, 2011

This book is intended for students and scientists working in the field of DNA repair, focusing on a number of topics ranging from DNA damaging agents and mechanistic insights to methods in DNA repair and insights into therapeutic strategies. These topics demonstrate how scientific ideas are developed, tested, dialogued, and matured as it is meant to discuss key concepts in DNA repair. The book should serve as a supplementary text in courses and seminars as well as a general reference for biologists with an interest in DNA repair.

\title{
How to reference
}

In order to correctly reference this scholarly work, feel free to copy and paste the following:

Bedia Cakmakoglu, Zeynep Birsu Cincin and Makbule Aydin (2011). Effect of Oxidative Stress on DNA Repairing Genes, Selected Topics in DNA Repair, Prof. Clark Chen (Ed.), ISBN: 978-953-307-606-5, InTech, Available from: http://www.intechopen.com/books/selected-topics-in-dna-repair/effect-of-oxidative-stress-ondna-repairing-genes

\section{INTECH}

open science | open minds

\section{InTech Europe}

University Campus STeP Ri

Slavka Krautzeka 83/A

51000 Rijeka, Croatia

Phone: +385 (51) 770447

Fax: +385 (51) 686166

www.intechopen.com

\section{InTech China}

Unit 405, Office Block, Hotel Equatorial Shanghai

No.65, Yan An Road (West), Shanghai, 200040, China 中国上海市延安西路65号上海国际贵都大饭店办公楼405单元

Phone: +86-21-62489820

Fax: $+86-21-62489821$ 
(C) 2011 The Author(s). Licensee IntechOpen. This is an open access article distributed under the terms of the Creative Commons Attribution 3.0 License, which permits unrestricted use, distribution, and reproduction in any medium, provided the original work is properly cited. 